\title{
Analysis of flood disaster response preparedness in Gampong Seulalah Langsa Lama Sub-District Langsa City
}

\author{
Ramdan Afrian ${ }^{1, *}$, Zukya Rona Islami ${ }^{1}$, Bachtiar Akob ${ }^{2}$, Hamdani $^{3}$, and Sofyan ${ }^{4}$ \\ ${ }^{1}$ Geography Education, Samudra University, Langsa City, Aceh, Indonesia \\ ${ }^{2}$ History Education, Samudra University, Langsa City, Aceh, Indonesia \\ ${ }^{3}$ Mechanical Engineering, Samudra University, Langsa City, Aceh, Indonesia \\ ${ }^{4}$ Mathematics Education, Samudra University, Langsa City, Aceh, Indonesia
}

\begin{abstract}
Langsa City is one of the City in Aceh Province that suffer from flood disaster almost every year. This research aims to analyze the extent of preparedness of community disaster response of Gampong Seulalah Langsa Lama in Langsa City in the event of the flood disaster. The type of this research is experimental research with phenomenology method. Data processing is done by performing data organizing, reading, and coding. The researchers also made an edge note of the data obtained. Furthermore, researchers conducted development of textural description and structural description. Finally, the researchers described the data obtained. The results of this study indicate that the level of preparedness of community disaster response of Gampong Seulalah Langsa Lama Sub-district in Langsa City is still low. This is due to the level of public awareness on the importance of disaster risk reduction through the response to the disaster is still very minimal. Advice from researchers, the need for a rigorous training effort to increase public awareness on the importance of community disaster response attitude to minimize the risk of the flood disaster. Good disaster preparedness will generate a good response and may minimize disaster risks.
\end{abstract}

\section{Introduction}

Indonesia is a country with a wide range of potential, both positive and negative. The positive potentials include wealth of biodiversity and animal diversity, high tourism potential due to the beauty of nature as well as high soil fertility. Yet, on the other hand, Indonesia also has the potential for harm in the form of various kinds of disasters. These disasters include high rates of earthquakes, landslides and a variety of hydrometeorological disasters.

The position of Indonesia that resides in the tropics has the potential of water overflow due to high annual rainfall. In addition, Indonesia also is among the 3 active tectonic plates with many mountains, hills, and many watersheds. The potential benefit can be transformed into potential hydro-meteorological disasters if not managed properly.

Hydro-meteorological disaster is a disaster that is common in Indonesia. It is reinforced with quick response Action statement (ACT) on any of the articles online stating that "disaster records released with the BNPB conclusion $92 \%$ of the disasters that are happening in Indonesia is disa a different causes. Dstrous Hydrometeorology". Types of disasters include flooding, flash flooding or mudslides. This statement is proven in Gupta; Parry in (Sutopo Purwo Nugroho: 2008) which claimed that "of the many natural disasters, flood was a disaster that had a great frequency" also supports the above statement.

Flood has occurred in Indonesia many years ago but has a different causes. During the years of 1970-80s, the disasters were very often in that almost all regions of Indonesia experienced the events. Floods in Indonesia between then and now has distinctive characters. The difference lies in scale and causes. During the 1970-80s the main cause of floods is natural factors. After that period, the causes of floods become more complex, among others, social economic and cultural factors. The scale of floods has become greater due to the development of the region that is not supported by flood control systems. This can be seen from the low ability of drainage draining the area woke up and the low capacity of the entire flood control facility (Sutopo Purwo Nugroho: 2008).

BNPB stated that "the number of the persons exposed to the risk of catastrophic flooding with the number exceeded 170 million and asset value exposure to exceed 750 Trillion rupiahs" (disaster risk Indonesia, 2016). Aceh is also included in disaster-prone areas hit by flooding. In the matrix the flood released BNPB, Aceh

Corresponding author: ramdan,afrian_geo@unsam.ac.id 
was in position 15 in the flood and are at the 7th position in case of flash floods.

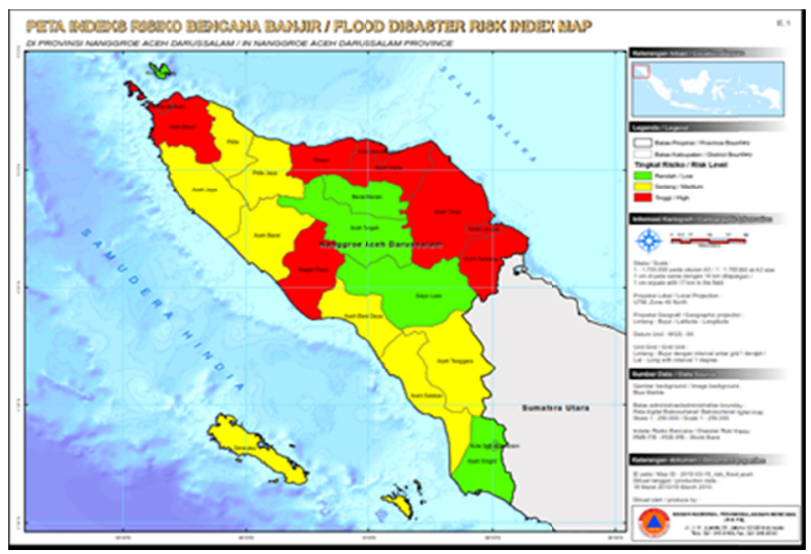

Fig. 1. Flood disaster risk index map

The picture (Fig. 1.) above shows the catastrophic flood-prone areas in Aceh province, and one of them is a city of Langsa. Langsa is located at an altitude of $0-25$ meters a.s.l. (Above sea level). But most areas of the city to the Southwest Langsa is the Mainland Beach, with elevation ranges at an altitude of about 8 ma.s.l. The southern part is the wavy folds are the mountain, with an elevation range at an elevation of approximately $75 \mathrm{~m}$ above sea level, while the eastern part there is a sludge swamp also with the amount of the distribution. In addition, the region also has Langsa lowlands and undulating and rivers (Book of Sanitation Langsa: 2013). Based on the circumstances of this topography, langsa often experiencing natural disasters.

The Government of Indonesia and the local government is in charge of implementing disaster mitigation (Law No. 24 of the year 2007). The Government requires citizens to have the knowledge and preparedness in the face of a disaster to reduce risks to disaster (Dodon, 2013). Citizens will be more ready and the negative impact brought about by such a disaster will be smaller if they have the attitude of preparedness.

The phenomenon of flooding in Gampong Seulalah requires preparedness to confront the Government and citizens of the disaster. This research aims to know the extent to which the level of readiness of the Gampong Seulalah citizens disaster response against the flood.

Dodon in Devi Erlia (2017) stated that in discussing preparedness there are some points that are a staple of discussion, among other things:

\subsection{Knowledge and attitude toward catastrophe}

Knowledge against disasters is the main reason a person to perform protection activities or existing preparedness efforts. Indicators of the knowledge and attitude of individuals/households are basic knowledge that should be owned by the individual includes knowledge about the disaster, causes and symptoms, and what to do in case of flooding.

\subsection{Emergency response plan}

The emergency response plan is a plan that is owned by the individual or the citizens in the face of an emergency in an area due to natural disasters.

\subsection{Early warning systems}

Warning signs include warning systems and distribution of the information if it will be a disaster. A good system is a system where citizens also understand the information that will be provided by these early warning signs or know what to do if disaster early warning sign goes off/on.

\subsection{Resources to support}

These indicators generally see a variety of needed resources of individuals or citizens in recovery efforts or survive in conditions of disaster or emergency. Resources support comes from internal and external from the affected area. Resources according to Sutton and Tierney is divided into 3 parts, namely human resources, funding resources/logistics, and resources technical guidance and material provides.

\subsection{Social capital}

Social capital is often defined as the ability of the individual or group to work with other individuals or groups. Citizens or individuals who have a better social bond with each other it would be easier to conduct preparedness. A good social capital among residents in the region was vulnerable to disasters would reduce the vulnerability itself.

\section{The material and method}

This study uses qualitative methods with the phenomenology of approach attempting to see as deep as possible events that occur in the community. The method of Phenomenology, according to Polkinghorne (Creswell, 1998) in Nurlailah Umar (2013) phenomenology Study describing the meaning of a life experience for some people about a concept or phenomenon. People involved in the deal with a phenomenon exploring consciousness structure of human life experience. While according to Husserl (Creswell, 1998) in Nurlailah Umar (2013) phenomenological researchers trying to find about things that need to be (essential), the structure of invariant (the essence) or the meaning of the fundamental experience and emphasis on intensity of awareness where the experience consists of things that look from the outside and the things that are in the consciousness of each based on memory, image, and meaning.

In conducting this study, the researcher as a human instrument, the function sets the focus of the study, with the help of tools such as interview notes, the recorder as evidence that researchers have been conducting 
interviews in participants ' attendance researchers known to the participant. Then research questions examined to investigate the meaning of the experience of the participants and asked him to explain the experiences when experiencing a disaster.

This study is expected to obtain data and information on the subject of discussion in disaster preparedness as well as to discuss the causes of the flood. Data processing is done by performing data organizing, reading and coding data. The researchers also made an edge note of the data obtained. Furthermore, researchers do development of textural description and structural description. Finally, researchers narrate the data obtained as shown in Fig. 2 .

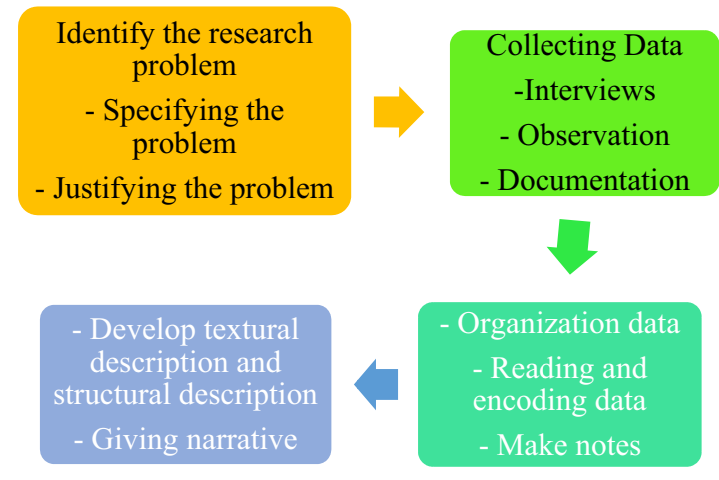

Fig. 2. Flood disaster risk index map

\section{Result and discussion}

Aceh is one of the flood-prone areas in Indonesia. The Aceh area that has great insecurity in the flood problem is an area of the East Coast including the city of langsa. That is because the eastern region is one of the ramps. Recorded many occurrences of flooding that occurred in the town of langsa. It is definitely causing harm in the form of damage to the goods as well as decreased quality of health.

The flood happened on watersheds (DAS) Krueng Langsa that hits some existing gampong in langsa. This flood event strikes a number of villages in the town of Langsa, namely Tanjung Gampong, Old Garden, Seulalah, Sidoarjo, Sidodadi, Meurandeh, and Gampong Recently. The last flood incident occurred in May 2017.

In Disaster-prone Indonesia Index (2011) explained that "Flooding is runoff water that exceeds the height of the face the normal water, so the riverbed overflow caused inundation in the presence of low land on the side of the river". Naturally, the flood is often caused by the abundance of water caused by high rainfall intensity. But in addition, there are several other factors, among others, drainage, sedimentation, debris and buildings around the banks of the river.

The result of the research shows that the level of preparedness of disaster response for the citizens of Gampong Seulalah can be said to be low. This is based on interviews with informants. The informants stated that only a few of the villagers had a prior understanding of preparedness. This is because the level of awareness of the people about the importance of disaster risk reduction through response to the disaster is still minimal. The importance of serious training is needed to raise citizens 'awareness of the importance of citizens' responses to disaster response in order to minimize flood disaster risk

A knowledge attitude and caring affect owned citizens to ready and response in anticipation of disasters, especially for those who live in disaster-prone areas (Indawati, 2015). Knowledge and attitude of disaster response that is owned by the citizens obtained from the experience of experiencing floods almost every year.

In detail preparedness of the disaster can be seen in the following explanation.

\subsection{Knowledge and attitude toward catastrophe}

In this case, the people of Gampong have knowledge about flood disaster that threatens their village. The informant stated, "most of the gampong residents know that flood disaster is a threat in their environment". But their knowledge is only limited to rain as the main cause of this problem. So that impact on their attitude in the face of disaster.

At the time of the disaster, they responded with a crude action. The results of interviews of residents stated that "storing valuables or fleeing to nearby civilian homes" is a step taken when a flood occurs. Residents are also not too concerned with the causes of other disasters such as flooding drainage, garbage, and construction.

Poor drainage is one of the causes of the occurrence of floods. Less drainage water causes are hampered to flow. This led to a pool so that when high intensity can lead to the occurrence of floods. The drainage system on the citizens of the gampong seulalah pertained less to accommodate a high amount of water when the rainy season comes as shown in Fig. 3.

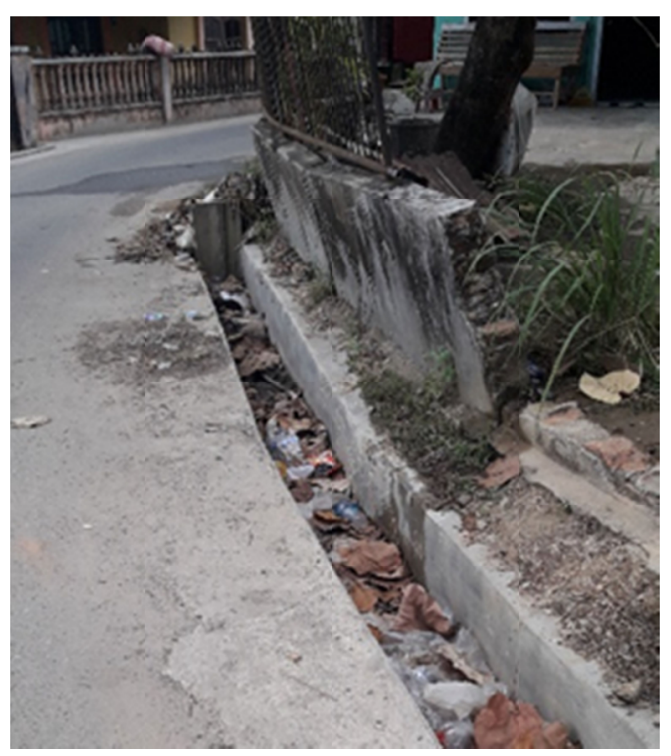

Fig. 3. Closed drainage waste and dead end

Other problems that occur in gampong seulalah is garbage in the river. Habits of the citizens (in Indonesia) 
that often throw away trash in the torso of the river has also become a factor supporting the occurrence of floods. Garbage causes the obstruction of the flow of the river especially when it's been piling up at the doors of the water. Apart from that pile of junk can also cause the volume capacity of the river being reduced.

The view of garbage in the gampong river body seulalah hinted that residents are still less concerned with the cleanliness of the river. Based on information from informants it is known that there are still residents who throw garbage in the river but the number is not much. thus it can be concluded that most garbage comes from other villagers who throw garbage in the river or come from the upstream carried by the current as shown in Fig. 4.

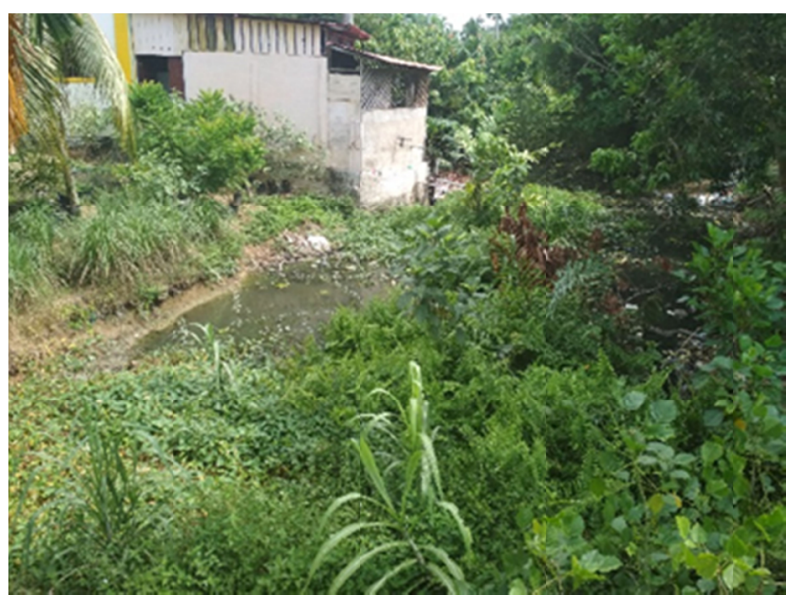

Fig. 4. The garbage in the river

The development process on the side of rivers or riverbanks also became a cause factor in addition to the above two factors. It can be seen in waste streams as well as several buildings located in the river. Construction on the banks of the river spaces can also lead to reduced runoff. Other than that the development is also often lead to the process of infiltration into the ground can be hampered due to paving of roads by asphalt or cement. The water comes from rain is not absorbed completely into the soil and water runoff which Beeline torso water. The excess volume of water that goes into the river may lead to flooding.

\subsection{Emergency response plan}

The emergency response plan is a plan that is owned by the individual or the citizens in the case of an emergency in an area due to natural disasters. Emergency response plans are an important part in the process of disaster response preparedness, mainly associated with evacuation, rescue, so that victims can be minimized (Firmansyah, 2014). Three types of action the emergency response that is modifying a residence, providing first aid supplies and medications and provide an alternative explanation.

Gampong Seulalah yet has a good emergency response plan. It is visible from the house that still treads the ground. Other than that not yet prepared in the face of disaster. He has not yet proven the system of early warning and disaster response flow when the disaster occurred. There is no alternative explanation of the tools also strengthens the assumption that has not been the existence of the emergency response plan at gampong.

\subsection{Early warning systems}

Warning signs include warning systems and distribution of the information if it will be a disaster. Warning signs include warning systems and the delivery of information in case of disasters (Dodon, 2013). The results of the processing of data show the majority of citizens who are in gampong seulalah makes the intensity of rain fell as the source of the information considered by the citizens. This consideration is based on the experience of the citizens in the face of catastrophic flooding. The citizens of the States "when the heavy rain and flooding to occur then it is likely old high". It was a benchmark in the face of catastrophic flooding.

Based on observations in the field also obtained that the citizens of the gampong seulalah do not yet have disaster warning systems, traditional and modern. Yet the existence of a siren or other warning system is not yet possible because of the magnitude of the level of awareness of the citizens of the dangers of flooding. It is closely related to levels of education and income of respondents are still low so that it will also affect the attitude of the existing disaster response preparedness at the residents. In addition to flooding as well as commonplace or usual things happening in gampong seulalah.

\subsection{Resources to support}

Several types of resources that can support improved preparedness are human resources: Gampong seulalah has a pretty good human resource. Note that the average family has a job as head of government officials (the civil servants). So it can be inferred that the citizens have sufficient income and have a level of education.

Funding resources: in accordance with government programs that will provide considerable funds for the village (Gampong) then it should be gampong has a good funding resource to build infrastructure in preparedness for disasters especially catastrophic flooding.

Resources technical guidance: In this case in Gampong Seulalah unprecedented technical guidance about the flood of good government as well as environmentalists. This information is obtained directly from the author of the interview along with a pack of geuchik and the village Secretary. Resources technical guidance is indispensable for regional disaster-prone. At gampong seulalah indispensable resources technical guidance to flood as the giver of knowledge and guidance about flood prevention and disaster relief. This will minimize the risk of disaster. 


\subsection{Social capital}

Dyah Rahmawati Hizbaron (2014) States that "in the social capital contained some important elements that build up the definition, namely: emotional Bond deals, resource groups, and residents there are goals to be achieved"

The citizens of gampong seulalah can be said to have an emotional attachment. They get to know each other a lot even still have blood relations. So, of course, arises a sense of security and trust on each of its citizens. It is proven by the convenience of the citizens feel leaving the House at the time fled.

Citizens have the same purpose at the time of fulfilling the program made by the head of the gampong. But by the time the flood took place in common purpose is not visible, as well as the recognition of one of the residents who stated that "at a time when the flood happened busy citizens save themselves and the goods each" have not led to cope with disaster flood times.

From the explanation above, so it's pretty obvious that the level of citizen preparedness gampong seulalah quite low. That it took the existence of guidance or education about disaster mitigation which there is preparedness in the face of disaster. This explanation is supported by Mirza Despandi (2014) States that "the participation of the citizens is required to reduce and avoid the risk of disaster important done by raising awareness and capacity of citizens". It is possible if the disaster included themes into the curriculum. So students know, understand and have awareness in handling the disaster.

Apart from that social capital owned by the gampong seulalah is expected to be a best practice that it can create gampong disaster preparedness. Utilizing this, coupled with existing resources, residents along the device gampong can make disaster mitigation plans. Gampong can also create early warning systems, as well as the designing an action in the face of preparedness.

Conclusion on the basis of the real process is then to be drawn the conclusion that the level of citizen preparedness response gampong seulalah can be said to be lacking. It appears to be from a bad drainage, lack of awareness of disaster preparedness. The lack of response preparedness also looks at not just early warning systems and emergency response planning as well as not utilized social capital in the face of catastrophic flooding.

Education and technical guidance on disaster mitigation are expected to be applied to citizens of the gampong seulalah. Thus the awareness and preparedness in the face of disasters will arise on the citizens of the gampong seualalah. so it's ready in the face of disaster whenever wherever.

\section{Conclusion}

Disaster preparedness is an important factor that must be owned by the community. Good disaster preparedness will generate the good response and can minimize disaster risk. Based on the problem of research and data analysis, it can be concluded that the preparedness of the people of the gampong seulalah against the flood disaster is stsill low.. This can be seen from the five indicators of disaster preparedness, namely:

4.1 Knowledge and attitude towards community disaster is still low. Public response is only limited to evacuate during floods. People do not understand what causes the floods, people still littering and do not pay attention to the state of drainage.

4.2 Emergency Response Plan, gampong Seulalah does not yet have a good emergency response plan. This is evident from the shape of the house still tread land.

4.3 Early warning system, based on observation in the field also found that citizens gampong seulalah not yet have a disaster warning system, both traditional and modern. The absence of sirens or other warning systems

4.4 Supporting resources, human resources, and funding in gampong are good enough. but technical guidance resources still do not exist.

4.5 Social capital, social capital in gampong seulalah already good, but has no similarity in the purpose of overcoming the flood disaster

\section{References}

1. Anonim. ssk Kota Langsa 2015-2019. Bab II. Profil Sanitasi (Online).

http://ppsp.nawasis.info/dokumen/perencanaan/sanit asi/pokja/newssk/kota.langsa/Bab\%20II\%20Profil\% 20\%20Sanitasi\%20Final.pdf. Diakses pada 23 Maret 20.30

2. Anonymous. Law No. 24 of 2007. Regarding Disaster Reconstruction

3. Anonim, (2010) Langsa City Sanitation Strategy. Sanitation Settlement Development Acceleration Program - PPSP-2010

4. Devi Erlia, Rosalina Kumalawati, Nevy Farista Aristin. (2017). Citizens and Govermment Preparedness Analysis Facing Flood Disasters in Martapura Barat District. Banjar Regency. Journal of Geography Education (JPG). Volume 4, No 3, Mei 2017.2 (Online) http://ppjp.unlam.ac.id/journal/index.php/jpg/article/ view/3525/3053. Accesed at 17 Februari 2018. Pukul 00.07.

5. Dodon. (2013). Indicators and Behavior of Preparedness of Residents in Populated Settlements in Anticipation of Various Flood Disaster Phases. Regional and City Planning Journal. Vol 21/2 August 2013 (online).

http://www.sappk.itb.ac.id/jpwk/wpcontent/uploads/ 2014/02/Jurnal9 Dodon. pdf.

6. Dyah Rahmawati Hizbaron, R. Rijanta, M.Baiquni. (2014). Social Capital in Disaster Management. Gadjah Mada University Press. Yogyakarta.

7. Firmansyah, Iman dkk. (2014). The Correlation Between Knowledge and behavior preparedness in Facing of Floods And Landslides disaster in adolescents aged 15-18 in SMA Al-Hasan Kemiri 
Sub district Panti of Jember Regency. Student Research Results Scientific Article, 2014. (online). http://repository.unej.ac.id/bitstream/handle/123456 789/60652/Iman\%20Firmansyah.pdf? sequence $=1$. Diakses pada 21 Maret 2017 pukul 19.25 WIB.

8. Indawati, Lilik. (2015). Analysis of Flood Severity and Citizen Perception on Flood Reduction Efforts in 24 Baureno Subdistrict, Bojonegoro District (Implementation as a learning resource for 7 th grade students of Baureno Junior High School 2, on Topics: Natural conditions and population activities. Sub Topic: Habitat and activities of Indonesian population).Tesis. Surakarta : Universitas Sebelas Maret Surakarta. (Online).

http://download.portal=garuda.org/article.php?articl $\mathrm{e}=431017 \& \mathrm{val}=7727 \&$ title $=$ ANALISIS $\% 20$ TINGK AT\%20KERAWANAN\%20BANJIR\%20DAN\%20 PERSEPSI\%20WARGA\%20TERHADAP\%20UPA YA\%20PENGURANGAN\%20DAMPAK\%20BAN JIR\%20DI\%20KECAMATAN\%20BAURENO\%20 KABUPATEN\%20BOJONEGORO. Diakses pada 23 Maret 2017 Pukul 20.15 WIB.

9. Mirza Desfandi. (2014). Urgency of Disaster Education Curriculum Based on Local Wisdom in Indonesia. Socio-Didactics:Social Science Education Journal (Online).
http://journal.uinjkt.ac.id/-index.php/SOSIOFITK/article/view/1261/1127. Diakses pada 31 Maret 2018. Pukul 22.11

10. Mohd. Robi Amri, dkk. (2016). Indonesian Disaster Management, BNPB. Jakarta.

11. Nurlaiah Umar, (2013), Knowledge and Preparedness of the Community Facing Flood Disasters in Bolapapu, Kulawi Sigi District, Central Sulawesi: Nursing Journal Soedirman. (On line)Vol 8. No 3. November 2013. Accesed at 20 Februari 2018. 22.10 o'clock.

https://media.neliti.com/media/publications/104928ID-pengetahuan-dan-kesiapsiagaan-masyarakat.pdf.

11. Lilik Kurniawan, dkk. (2011). Indonesia disaster prone index in 2011. BNPB. Jakarta

12. Sutopo Purwo Nugroho. (2008). Rainfall Analysis Causes Large Floods in Jakarta In Early February 2007. Air Indonesia Journal (JAI). cana indonesia in 2011Vol. 4. No. 2 Tahun 2008 (Online).

http://ejurnal.bppt.go.id/ejurnal2011/index.php/JAI/ article/view/270/270. Accesed at 17 February 2018. 00.13 o'clock. 